\title{
Genetic variation of Ginkgo biloba L. (Ginkgoaceae) based on cpDNA PCR-RFLPs: inference of glacial refugia
}

\author{
L Shen $^{1,3}$, X-Y Chen ${ }^{1}, X$ Zhang $^{1}$, Y-Y Li ${ }^{1}, \mathrm{C}-\mathrm{X} \mathrm{Fu}{ }^{2}$ and Y-X Qiu ${ }^{2}$ \\ ${ }^{1}$ Department of Environmental Sciences, East China Normal University, Shanghai 200062, China; ${ }^{2}$ Lab of Plant Systematic Evolution \\ and Biodiversity, College of life Science, Zhejiang University, Hangzhou 310029, China
}

\begin{abstract}
Ginkgo biloba, a famous living fossil, is the sole survivor of the genus Ginkgo. To make inferences about the glacial refugia that harbored $G$. biloba, we examined the genetic structure of eight potential refugial populations and plantations using chloroplast DNA (cpDNA) with eight size variants in the trnK1-trnK2 fragment. The data consist of haplotypes from 158 trees collected from eight localities. The majority of the cpDNA haplotypes are restricted to minor portions of the geographical range. Our results suggest that refugia of
\end{abstract}

G. biloba were located in southwestern China. This area is a current biodiversity hotspot of global importance, and may have been protected from the extremes of climatic fluctuations during the Pleistocene. The Ginkgos on West Tianmu Mountain, which were previously considered to be wild by many researchers, may, instead, have been introduced by Buddhist monks.

Heredity (2005) 94, 396-401. doi:10.1038/sj.hdy.6800616

Published online 10 November 2004

Keywords: chloroplast DNA; PCR-RFLPs; geographic variation; glacial refugia; Ginkgo biloba

\section{Introduction}

The distribution and genetic diversity of plant species have been deeply modified by Pleistocene glaciations (Comes and Kadereit, 1998; Hewitt, 1999, 2004; Newton et al, 1999; Abbott and Brochmann, 2003). During glaciations, the ranges of species changed and some ancestral populations became extinct, and recolonization subsequently occurred during interglacial periods (Widmer and Lexer, 2001). The species genomes were dramatically influenced by these processes, and molecular markers can be used to infer the phylogeographic pattern of species in response to the Pleistocene climatic changes (Newton et al, 1999; Shen et al, 2002; Abbott and Comes, 2004).

In contrast to intense investigations on plants of Europe and northern America (Hewitt, 2000; Shen et al, 2002), understanding of the effects of past climatic events on population structure and phylogeny of species in Asia is relatively limited (Szmidt and Wang, 1993; Wang and Szmidt, 1994; Szmidt et al, 1996; Chen et al, 1997; Tomaru et al, 1997; Lin, 2001; Huang et al, 2002; Lu et al, 2002; Okaura and Harada, 2002; Aoki et al, 2004). The Eurasian ice sheets covered millions of square kilometers of the continent in the late Pleistocene period (Svendsen et al, 1999). It is accepted that, during the Quaternary, mountains over $3500 \mathrm{~m}$ in western China became glaciated, but there is disagreement over whether the

Correspondence: $X-Y$ Chen, Department of Environmental Sciences, East China Normal University, Zhongshan Road (N.) 3663, Shanghai 200062, PR China.E-mail: xychen@des.ecnu.edu.cn

${ }^{3}$ Current address: Department of Plant Biology, The University of Georgia, Athens, GA 30602, USA.

Received 15 September 2004; accepted 23 September 2004; published online 10 November 2004 lower central and eastern mountains $(<3000 \mathrm{~m})$ were glaciated (Shi et al, 1989). Temperatures are estimated to have been $5-13^{\circ} \mathrm{C}$ lower than at present in China (Shi et al, 1989): low enough to have profound impact on plants (Wang and Liu, 1994).

Ginkgos (Ginkgoaceae) have a history dating back approximately to the early Permian ( $280 \mathrm{MA})$ (Willis and McElwain, 2002). At the height of their global radiation, fossil evidence indicates that there were at least 16 genera and that they formed a significant part of the world vegetation (Willis and McElwain, 2002). Today, they are represented by a single species, Ginkgo biloba, which is endemic to China. This species was listed as a rare species in the 1997 IUCN red list of threatened plants (http://www.unep-wcmc.org/) and listed in the red list of endangered plant species of China ( $\mathrm{Fu}$ and Jin, 1992). Thus, it should receive effective conservation. However, the existence of natural G. biloba populations is disputed and the refugia during Pleistocene glaciations are not known (Liang and Li, 2001). The West Tianmu Mountain of Zhejiang Province is one likely refugium (Liang and Li, 2001; Lin and Zhang, 2004). Recently, several papers have suggested that some other sites had native populations, based on plant community surveys and human settlement history (Zhou et al, 1982; Xiang and Xiang, 1997; Xiang et al, 1998; Li et al, 1999), although this evidence might be considered inconclusive.

Molecular markers have proved to be useful tools for identifying refugia and tracking postglacial migration routes of plant species. Chloroplast DNA (cpDNA) is maternally inherited in most flowering plants and some gymnosperms (such as Ginkgo, Cycas and Ephedra) (Mogensen, 1996). It therefore provides a seed-specific marker. Maternally inherited markers tend to display 
highly structured geographical distribution because of the lower potential for dispersal by seeds than by pollen (Newton et al, 1999). It is consequently easier to elucidate the refugia and migration history of plant species using maternally inherited markers (rather than biparently inherited ones) (Newton et al, 1999). In the present paper, we try to understand the cpDNA haplotype diversity of G. biloba, and to infer the potential refugia.

\section{Materials and methods}

\section{Species and sampling}

G. biloba is a long-lived deciduous species. It occurs through most of mainland China and many other countries. However, most trees have been planted for ornamental or medical purposes. Several sites were reported to have natural Ginkgo based on plant community surveys or/and the history of human settlement (Table 1). We will call them 'natural' populations because no convincing evidence exists to the contrary. We sampled populations covering these sites (six populations) as well as two additional planted populations (Table 1, Figure 1). They can be divided into three regions: southwestern China (JF, TL and SP), eastern China (TM, CX and YS) and central China (LY and XA).

Buds were collected from trees in West Tianmu Mountain (TM) and brought fresh to the laboratory for DNA extraction, while leaves were collected from individuals of the other seven populations and dried using silica gel has described previously (Chase and Hills, 1991). In all, 11-27 trees were sampled from each location. In order to avoid sampling recently planted trees, we sampled those with a DBH (diameter at breastheight) as large as possible. The DBH of the sampled trees ranged from 39 to $210 \mathrm{~cm}$, of which only 10 (three in SP and TM and four in XA population) were less than $50 \mathrm{~cm}$ (Table 1).

\section{DNA extraction}

Total DNA was extracted using a miniprep CTAB protocol modified from Doyle and Doyle (1987). Dry leaves were ground to powder with a cold grinder, suspended in $750 \mu \mathrm{l} 60^{\circ} \mathrm{C}$ CTAB $2 \times$ buffer and incubated for $90 \mathrm{~min}$. After chloroform isoamyl extraction, the aqueous phase was collected and digested with RNase A for $30 \mathrm{~min}$. Finally, the nucleic acid was precipitated with $100 \%$ ethanol and resuspended in TE buffer.

\section{PCR-RFLP of cpDNA}

PCR assays were performed in $50 \mu$ l total volume containing $0.2 \mu \mathrm{M}$ of each primer, $10 \mathrm{mM} \mathrm{KCl}, 8 \mathrm{mM}$ $\left(\mathrm{NH}_{4}\right)_{2} \mathrm{SO}_{4}, 10 \mathrm{mM}$ Tris- $\mathrm{HCl}(\mathrm{pH} 9.0), 2.5 \mathrm{mM} \mathrm{MgCl}$, $200 \mu \mathrm{M}$ dNTPs, $2 \mathrm{U}$ of Taq DNA polymerase and $40 \mathrm{ng}$ template DNA. In total, 16 pairs of universal primers for noncoding regions of cpDNA (Taberlet et al, 1991; Demesure et al, 1995; Dumolin-Lapegue et al, 1997b) were used in initial screening. No product was obtained using primers for trnfM-psaA, trnV-rbcL and $t r n \mathrm{~F}-t r n \mathrm{~V}$ (Dumolin-Lapegue et al, 1997b).

Fragments of $\operatorname{trn} \mathrm{H}-\operatorname{trn\mathrm {K}}, \operatorname{trn} \mathrm{C}-\operatorname{trn} \mathrm{D}, p s a \mathrm{~A}-t r n S, t r n \mathrm{~S}-$

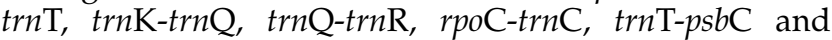
trnT-trnF were of low quality and not suitable for RFLP analysis. The other four pairs of primers for $\operatorname{trn} \mathrm{K} 1-\operatorname{trn} \mathrm{K} 2$, trnD-trnT, psbC-trnS and trnS-trnfM produced fragments of suitable quality, which then were digested with the endonucleases RsaI, HinfI and HaeIII, respectively. After digestion at $37^{\circ} \mathrm{C}$ for $6 \mathrm{~h}$, the products were resolved electrophoretically on either $2 \%$ agarose gels or $8 \%$ polyacrylamide gels stained with ethidium bromide and photographed using Bio-Rad Gel Doc ${ }^{2000}$.

\section{Data analysis}

Diversity measures were calculated directly on the haplotype frequencies using Lewis and Zaykin's (2000) GDA program (version $1.0 \mathrm{~d} 15$ ). The number of

Table 1 Location and sample size of G. biloba populations in the present study

\begin{tabular}{|c|c|c|c|c|c|c|c|}
\hline Population & Abbreviation & Sample size & $D B H(\mathrm{~cm})$ & Longitude & Latitude & Altitude $(m)$ & Description \\
\hline $\begin{array}{l}\text { Luoyang of Suizhou } \\
\text { City, Hubei Province }\end{array}$ & LY & 16 & $60-210$ & $113^{\circ} 19^{\prime} \mathrm{E}$ & $31^{\circ} 26^{\prime} \mathrm{N}$ & 134-198 & $\begin{array}{l}\text { Native community } \\
\text { (Zhou et al, 1982) }\end{array}$ \\
\hline $\begin{array}{l}\text { Xiaan of Xixia County, } \\
\text { He'nan Province }\end{array}$ & XA & 20 & 39-156 & $111^{\circ} 47^{\prime} \mathrm{E}$ & $33^{\circ} 32^{\prime} \mathrm{N}$ & $776-845$ & $\begin{array}{l}\text { Natural population } \\
\text { reported by the media }\end{array}$ \\
\hline $\begin{array}{l}\text { Jinfou Mountain of } \\
\text { Nanchuan County, } \\
\text { Chongqing } \\
\text { Municipality }\end{array}$ & $\mathrm{JF}$ & 24 & $58-151^{a}$ & $107^{\circ} 11^{\prime} \mathrm{E}$ & $29^{\circ} 03^{\prime} \mathrm{N}$ & 890-1301 & $\begin{array}{l}\text { Natural population ( } \mathrm{Li} \\
\text { et al, 1999) }\end{array}$ \\
\hline $\begin{array}{l}\text { Shaping of Guiyang } \\
\text { City, Guizhou Province }\end{array}$ & SP & 20 & 40-198 & $106^{\circ} 48^{\prime} \mathrm{E}$ & $26^{\circ} 15^{\prime} \mathrm{N}$ & 1272 & $\begin{array}{l}\text { Natural population } \\
\text { (Xiang and Xiang, 1999) }\end{array}$ \\
\hline $\begin{array}{l}\text { Tuole of Pan County, } \\
\text { Guizhou Province }\end{array}$ & $\mathrm{TL}$ & 24 & $56-203$ & $104^{\circ} 32^{\prime} \mathrm{E}$ & $25^{\circ} 36^{\prime} \mathrm{N}$ & 1632 & $\begin{array}{l}\text { Natural population } \\
\text { (Xiang et al, 2003) }\end{array}$ \\
\hline $\begin{array}{l}\text { Badujie of Changxing } \\
\text { County, Zhejiang } \\
\text { Province }\end{array}$ & CX & 16 & $60-94$ & $119^{\circ} 42^{\prime} \mathrm{E}$ & $31^{\circ} 01^{\prime} \mathrm{N}$ & $127-210$ & Plantations \\
\hline $\begin{array}{l}\text { Yushan of Yongxiu } \\
\text { County, Jiangxi } \\
\text { Province }\end{array}$ & YS & 11 & ND & ND & ND & ND & $\begin{array}{l}\text { Cultivated individuals } \\
\text { in a temple }\end{array}$ \\
\hline $\begin{array}{l}\text { West Tianmu Mountain } \\
\text { of Lin'an City, Zhejiang } \\
\text { Province }\end{array}$ & $\mathrm{TM}$ & 27 & $46-135$ & $119^{\circ} 27^{\prime} \mathrm{E}$ & $30^{\circ} 19^{\prime} \mathrm{N}$ & $440-1193$ & $\begin{array}{l}\text { Natural population } \\
\text { (Hu, 1954; Lin and } \\
\text { Zhang, 2004) }\end{array}$ \\
\hline
\end{tabular}

aAn individual's DBH was $3.69 \mathrm{~m}$ in 1950s. The trunk was destroyed by a fire in 1960s and sprouted again after the fire. We sampled leaves of sprouts of the tree.

ND: not determined. 
haplotypes and haplotype diversity $(\hat{\mathrm{h}})$ were calculated for each population and at region and species level, according to Nei (1987). Gene flow among populations was characterized as $\mathrm{Nm}$, the estimated number of female migrants per generation between populations, using the formula $F_{\mathrm{ST}}=1 /(1+2 \mathrm{Nm})$ where $N$ is the female effective population size and $m$ is the female migration rate.

\section{Results}

With the enzymes RsaI, HinfI and HaeIII, no variation was observed in restriction patterns of the amplification products of primers for trnD-trnT, psbC-trnS and trnStrnfM. Variants were observed for trnK1-trnK2 products when digested by RsaI, HinfI and HaeIII (Table 2). All the variants are caused by point mutations. Eight haplotypes were defined $(A-H)$. Three were common, with frequencies of 0.474 (haplotype E), 0.314 (haplotype B) and 0.160 (haplotype A), four were rare (frequencies equal to 0.006 for haplotype C, D, G and H), and haplotype F was infrequent, with a frequency of 0.026 .

Population JF has the highest effective number of haplotypes (2.53), followed by CX (2.51) and TL (1.52).
Similar trends are observed for the actual numbers of haplotypes (Table 3). Haplotype diversity $(\hat{\mathrm{h}})$ is greatest in population CX, followed by JF and TL (Table 3). One other population (LY), almost fixed for haplotype E, has one additional variant $(\hat{h}=0.121)$, and the remaining four population samples are fixed for one haplotype. The mean $\hat{h}$ is 0.214 and $\hat{h}$ at the species level is 0.652 . At the regional level, there are 7, 4 and 3 haplotypes for southwestern, eastern and central China, respectively. The value of $h$ ranges from 0.246 (eastern China) to 0.685 (southwestern China) with a mean of 0.485 . The overall value of $\theta$ is 0.676 (Walter and Epperson, 2001), and the estimate of $\mathrm{Nm}$ is 0.240 .

Nei's (1978) genetic distance reflects the same pattern of haplotype differentiation between pairs of populations (Table 4).

\section{Discussion}

\section{cpDNA polymorphism in G. biloba}

With three different restriction enzymes, eight different cpDNA haplotypes were found in 158 individuals (Table 2). The level of genetic variation is moderate

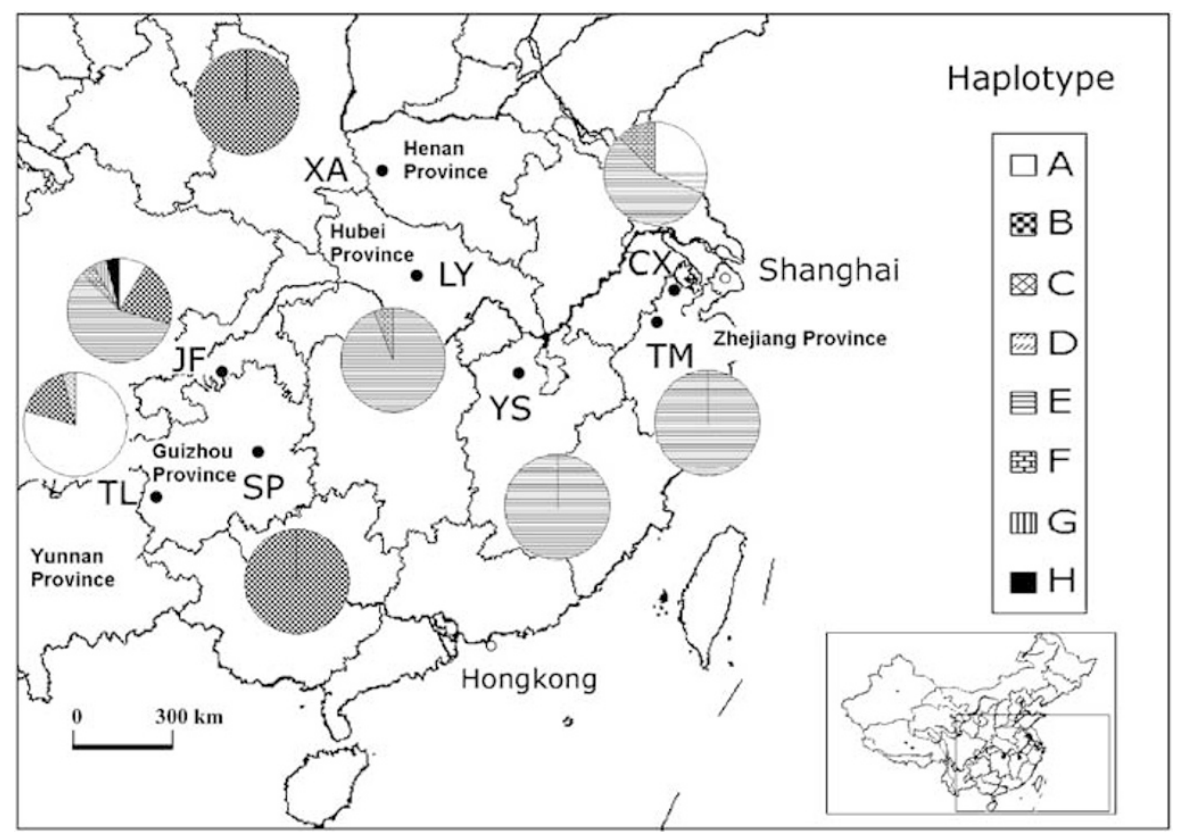

Figure 1 Geographic locations of eight populations of G. biloba in China. TL: Tuole of Pan County, Guizhou Province; CX: Changxing County, Zhejiang Province; LY: Luoyang of Suizhou City, Hubei Province; YS: Yushan of Yongxiu County, Jiangxi Province; SP: Shaping of Guiyang City, Guizhou Province; TM: West Tianmu Mountain of Linan City, Zhejiang Province; XA: Xiaan of Xixia County, He'nan Province; JF: Jinfou Mountain of Nanchuan County, Chongqing Municipality.

Table 2 Haplotype definitions, with the restriction profiles of $\operatorname{trn} \mathrm{K} 1-\operatorname{trnK} 2$ by each endonuclease, and measures of differentiation $(\theta)$ in the study populations of $\mathrm{G}$. biloba

\begin{tabular}{lccccccccc}
\hline Endonuclease & \multicolumn{10}{c}{ Haplotype } \\
\cline { 2 - 10 } & $A$ & $B$ & $C$ & $D$ & $E$ & $F$ & $G$ & Combined \\
\hline RsaI & $1^{\mathrm{a}}$ & 2 & 1 & 1 & 1 & 1 & 2 & 2 \\
HinfI & 1 & 2 & 1 & 2 & 1 & 2 & 1 & 1 \\
HaeIII & 3 & 2 & 2 & 2 & 1 & 1 & 2 & 1 \\
$\theta$ & 0.5943 & 0.7956 & -0.0116 & 0.0135 & 0.7586 & 0.0232 & -0.0116 & -0.0116 & 0.6764 \\
\hline
\end{tabular}

${ }^{\mathrm{a}} 1,2$ and 3 is code of the restriction profile. 
Table 3 Frequencies and diversity of haplotypes within study populations of G. biloba

\begin{tabular}{|c|c|c|c|c|c|c|c|c|c|c|}
\hline \multirow[t]{2}{*}{ cpDNA types } & \multicolumn{8}{|c|}{ Population } & \multirow[t]{2}{*}{ Total/mean } & \multirow[t]{2}{*}{ Total/mean without YS and CX } \\
\hline & $J F^{\mathrm{a}}$ & $T L$ & $S P$ & $T M$ & $Y S$ & $C X$ & $L Y$ & $X A$ & & \\
\hline A & 2 & 19 & 0 & 0 & 0 & 4 & 0 & 0 & 25 & 21 \\
\hline B & 5 & 4 & 20 & 0 & 0 & 0 & 0 & 20 & 49 & 49 \\
\hline $\mathrm{C}$ & 0 & 1 & 0 & 0 & 0 & 0 & 0 & 0 & 1 & 1 \\
\hline $\mathrm{D}$ & 0 & 0 & 0 & 0 & 0 & 1 & 0 & 0 & 1 & 0 \\
\hline $\mathrm{E}$ & 14 & 0 & 0 & 25 & 11 & 9 & 15 & 0 & 74 & 54 \\
\hline $\mathrm{F}$ & 1 & 0 & 0 & 0 & 0 & 2 & 1 & 0 & 4 & 2 \\
\hline G & 1 & 0 & 0 & 0 & 0 & 0 & 0 & 0 & 1 & 1 \\
\hline $\mathrm{H}$ & 1 & 0 & 0 & 0 & 0 & 0 & 0 & 0 & 1 & 1 \\
\hline No. of plants & 24 & 24 & 20 & 25 & 11 & 16 & 16 & 20 & 156 & 115 \\
\hline$A^{b}$ & 6 & 3 & 1 & 1 & 1 & 4 & 2 & 1 & $8 / 2.375$ & $7 / 2.333$ \\
\hline$A_{\mathrm{E}}{ }^{\mathrm{c}}$ & 2.53 & 1.52 & 1 & 1 & 1 & 2.51 & 1.13 & 1 & $2.86 / 1.46$ & $2.97 / 1.36$ \\
\hline$\hat{h}^{\mathrm{d}}$ & $0.617(0.067)$ & $0.351(0.077)$ & 0 & 0 & 0 & $0.621(0.070)$ & $0.121(0.075)$ & 0 & $0.652 / 0.214$ & $0.566 / 0.182$ \\
\hline
\end{tabular}

aPopulation codes are the same as in Table 1.

bNumber of different haplotypes.

'Effective number of haplotypes.

dHaplotype diversity. Numerals in brackets are standard errors.

Table 4 Genetic distance ${ }^{a}$ based on haplotype frequencies

\begin{tabular}{|c|c|c|c|c|c|c|c|c|}
\hline & $J F^{\mathrm{b}}$ & $T L$ & $S P$ & $T M$ & $Y S$ & $C X$ & $L Y$ & $X A$ \\
\hline JF & - & 1.5995 & 1.0887 & 0.0591 & 0.0591 & 0.0730 & 0.0544 & 1.0887 \\
\hline TL & & - & 1.5755 & $\infty$ & $\infty$ & 0.9186 & $\infty$ & 1.5755 \\
\hline SP & & & - & $\infty$ & $\infty$ & $\infty$ & $\infty$ & 0.000 \\
\hline TM & & & & - & 0.0000 & 0.0903 & 0.0001 & $\infty$ \\
\hline YS & & & & & - & 0.0903 & 0.0001 & $\infty$ \\
\hline CX & & & & & & - & 0.0756 & $\infty$ \\
\hline LY & & & & & & & - & $\infty$ \\
\hline XA & & & & & & & & - \\
\hline
\end{tabular}

aPairs denoted by $\infty$ were fixed for different haplotypes, and thus Nei's (1978) measure is undefined. Values of 0 occurred when pairs were fixed for identical haplotypes.

${ }^{\mathrm{b} C}$ Codes of population are the same as in Table 1.

compared to that of other plants, for example, three haplotypes in 52 Silene hifacensis individuals (Prentice et al, 2003), 10 cpDNA haplotypes in 188 Beta vulgaris ssp. maritima individuals (Forcioli et al, 1998), 13 haplotypes in 217 Alnus glutinosa individuals (King and Ferris, 1998) and 23 haplotypes in 1412 white oaks (Dumolin-Lapegue et al, 1997a).

At the regional level, southeastern China has the highest haplotype diversity and central China the lowest. Genetic variation at the population level is much more variable. Population JF has as many as six haplotypes, while the other four populations have only one haplotype. It is intriguing that CX has more haplotypes than some other sites and has the highest haplotype diversity (0.621). The CX population is believed to have been transplanted from other sites, hence artificial admixture can explain the high diversity, if introduced individuals were drawn from several populations (Wade and McCauley, 1988). High genetic diversity in nonrefugia population has been observed in other plant species. Pinus resinosa, for example, shows the highest diversity in previously glaciated areas (Walter and Epperson, 2001) due to the natural postglacial recolonization from different refugia.

It has been shown theoretically and empirically that the level of genetic differentiation among populations is expected to be higher for maternally inherited cpDNA markers than for biparentally inherited nuclear genes (Ennos, 1994; Raspe et al, 2000). In accordance with this expectation, a $G_{\mathrm{ST}}$ of 0.161 was observed for RAPD markers in G. biloba (Fan et al, 2004), whereas a much higher level of differentiation $(\theta=0.676)$ was found for cpDNA haplotypes in the present study. Limited gene flow and drift may contribute to the difference (Raspe et al, 2000).

\section{Glacial refugia of $G$. biloba}

The earliest known fossil of Ginkgo is from the Middle Jurassic epoch of $170 \mathrm{Myr}$ ago and evolutionary history became clear with a recent find (Zhou and Zheng, 2003). East Asia provided the later habitats of Ginkgo species, and fossils have been found from the Oligocene, Miocene, Pliocene and early Pleistocene in Japan (Uemura, 1997). It has been suggested that West Tianmu Mountain was the refuge of G. biloba during the last glaciations, although there has been some disagreement (Liang and Li, 2001; Lin and Zhang, 2004) due to lack of a detailed fossil record (Zhou, 2003).

The cpDNA variation reported here indicates strong genetic differentiation and shows that the spread of $G$. biloba since the last glaciation does not coincide with 
previous expectations. The pattern suggests that southwestern China was a refugium for G. biloba. Seven of the eight haplotypes were found there and three of them were endemic to this region.

It would not be too surprising if the refugium of G. biloba was located in SW China during the Pleistocene ice ages. SW China is located southeast of the Tibetan Plateau and south to the Qing Mountains. The plateau and mountains form a natural division between the temperate zone and subtropical zone in mainland China. Consequently, SW China was less affected by cold air from Siberia during the glaciations. This region has the greatest biodiversity in China due to the relatively stable environment and diverse topography. It is also one of the 25 global biodiversity hotspots (Myers et al, 2000). The Yunnan Province, for example, has been estimated to harbor more than 15000 vascular plant species. Many other living fossils are also found there. For example, Cathaya argyrophylla, Tetracentron sinense and natural Metasequoia glyptostroboides populations have been found in remote mountains of this region. Wang and Liu (1994) also suggested that this region is an important refugium for species surviving the Pleistocene glaciations.

The most likely refugium is sited in Jinfoshan, at the boundary of Chonqing Municiplity and Guizhou Province, as suggested by the current occurrence of ancient Ginkgo trees. Recently, a natural-like Ginkgo forest was reported in Jinfoshan by Li et al (1999) where there are 70 trees with $\mathrm{DBH}$ larger than $1 \mathrm{~m}$ and eight with $\mathrm{DBH}$ larger than $2 \mathrm{~m}$. The town was established about 200 years ago and the largest Ginkgo tree was estimated to be 2500 years old with a DBH of $3.69 \mathrm{~m}$ (Li et al, 1999). Wuchuan County of Guizhou Province, not far from Jinfoshan, was also reported to have a natural Ginkgo population (Xiang and Xiang, 1997; Xiang et al, 1998). We sampled and analyzed the Wuchuan population. However, for unknown reasons, no amplified product was obtained with the universal primers.

Population TL, located around the border of Guizhou Province and Yunnan Province, seems to be another potential refugium because a higher than average number of haplotypes was found there and one of the haplotypes is only found there. The historical record of human colonization also supports this conclusion. It has been reported that there were 918 ancient Ginkgo trees in and around Tuole Village of Pan County (Xiang et al, 2003). The oldest is older than 1000 years, whereas the village was established about 500 years ago (Xiang et al, 2003).

Population SP, not far from JF and TL, is fixed for haplotype $B$ that is not the most frequence haplotype in JF and TL. This may reflect loss of genetic variation due to a bottleneck during glaciation. Similarly, Ginkgo in other natural populations that may have become established after the retreat of the glaciers and bottlenecks during range expansion may explain the low haplotype diversity in these populations (Widmer and Lexer, 2001).

There are many papers discussing whether G. biloba population in Tianmu Mountain is natural or transplanted $(\mathrm{Hu}, 1954$; Liang and Li, 2001; Lin and Zhang, 2004). In 1954, Hu, who described the living fossil Metasequoia glyptostroboides, reported there were some wild individuals in Zhejiang besides the planted ones (Hu, 1954). Since then, several researchers have proposed that West Tianmu Mountain was the sole refugium of $G$. biloba (Lin and Zhang, 2004), while others disagreed (Liang and $\mathrm{Li}, 2001$ ). The present study indicates that West Tianmu Mountain does not seem to have served as a refugium for Ginkgos since there is only one common cpDNA haplotype. This conclusion is in agreement with the settlement history. West Tianmu Mountain is famous for temples. The oldest Old Temple, was built in $936 \mathrm{AD}$ The largest ginkgo tree is $123 \mathrm{~cm}$ in $\mathrm{DBH}$ and estimated to be about 500 years old. Hence, the Old Temple was built much earlier than the largest ginkgo tree. Of the many tree species planted around temples, the Buddhist monks preferred Ginkgo. As a result, there are many large ginkgo trees in or around temples in China, with some more than 1000 years old. Therefore, ginkgos in West Tianmu Mountain are likely to have been planted by monks, and may not be natural.

\section{Acknowledgements}

We thank Mrs Tianyi Wu of Biology Department of Marqueet University for reading and providing helpful comments on the manuscript and Mrs Shuzhen Yang of Bureau of Tianmu Mountain National Nature Reserve for providing help in collecting samples. We acknowledge two anonymous reviewers for criticial comments on an early edition of the manuscript and Dr David Rosenthal for improving the language. We also thank Professor Ying JS of Institute of Botany and Professor Jiang MX of Wuhan Institute of Botany for providing helpful information about G. biloba. The work was supported in part by the State Key Basic Research and Development Plan of China (G2000046806), Shuguang Scholar Program and '211' Program to X-Y Chen.

\section{References}

Abbott RJ, Brochmann C (2003). History and evolution of the arctic flora: in the footsteps of Eric Hulten. Mol Ecol 12: 299-313.

Abbott RJ, Comes HP (2004). Evolution in the Arctic: a phylogeographic analysis of the circumarctic plant, Saxifraga oppositifolia (Purple saxifrage). New Phytol 161: 211-224.

Aoki K, Suzuki T, Hsu T-W, Murakami N (2004). Phylogeography of the component species of broad-leaved evergreen forests in Japan, based on chloroplast DNA variation. J Plant Res 117: 77-94.

Chase MW, Hills HH (1991). Silica gel: an ideal material for field preservation of leaf samples for DNA studies. Taxon 40: 215-220.

Chen XY, Wang XH, Song YC (1997). Genetic diversity and differentiation of Cyclobalanopsis glauca populations in East China. Acta Bot Sin 39: 149-155.

Comes HP, Kadereit JW (1998). The effect of quaternary climatic changes on plant distribution and evolution. Trends Plant Sci 3: $432-438$.

Demesure B, Sodzi N, Petit RJ (1995). A set of universal primers for amplification of polymorphic non-coding regions of mitochondrial and chloroplast DNA in plants. Mol Ecol 4: 129-131.

Doyle JJ, Doyle JL (1987). A rapid DNA isolation procedure for small quantities of fresh leaf tissue. Phytochem Bull 19: 11-15.

Dumolin-Lapegue S, Demesure B, Fineschi S, Corre VL, Petit RJ (1997a). Phylogeographic structure of white oaks throughout the European continent. Genetics 146: 1475-1487.

Dumolin-Lapegue S, Pemonge M-H, Petit RJ (1997b). An enlarged set of consensus primers for the study of organelle DNA in plants. Mol Ecol 6: 393-398. 
Ennos RA (1994). Estimating the relative rates of pollen and seed migration among plants populations. Heredity 72: 250-259.

Fan XX, Shen L, Zhang X, Chen XY, Fu CX (2004). Assessing genetic diversity of Ginkgo biloba L. (Ginkgoaceae) populations from China by RAPD markers. Biochem Genet 42: 269-278.

Forcioli D, Saumitou-Laprade P, Valero M, Vernet P, Cuguen J (1998). Distribution of chloroplast DNA diversity within and among populations in gynodioecious Beta vulgaris ssp. maritima (Chenopodiaceae). Mol Ecol 7: 1193-1204.

Fu LG, Jin JM (1992). Red List of Endangered Plants in China. Science Press: Beijing.

Hewitt G (2000). The genetic legacy of the Quaternary ice ages. Nature 405: 907-913.

Hewitt GM (1999). Post-glacial re-colonization of European biota. Biol J Linn Soc 68: 87-112.

Hewitt GM (2004). Genetic consequences of climatic oscillations in the Quaternay. Phil Trans Roy Soc Lond B 359: 183-195.

$\mathrm{Hu}$ X-S (1954). Metasequoia glyptostroboides, Glyptostrobus pensilis and Ginkoo biloba. Biol Bullet Sin 12: 12-15.

Huang SSF, Hwang S-Y, Lin T-P (2002). Spatial pattern of chloroplast DNA variation of Cyclobalanopsis glauca in Taiwan and East Asia. Mol Ecol 11: 2349-2358.

King RA, Ferris C (1998). Chloroplast DNA phylogeography of Alnus glutinosa (L.) Gaertn. Mol Ecol 7: 1151-1161.

Li JW, Liu ZY, Tan YM, Ren MB (1999). Studies on the Ginkgo at the Jinfoshan Mountain. For Res 12: 197-201.

Liang LX, Li SN (2001). Argument about wild populations of Ginkgo. Sci Silvae Sin 37: 135-137.

Lin H, Zhang DH (2004). Analysis for the origin of Ginkgo population in Tianmu Mountain. Sci Silvae Sin 40: 28-31.

Lin T-P (2001). Allozyme variations in Michelia formosana (Kanehira) Masamune (Magnoliaceae), and the inference of a glacial refugium in Taiwan. Theor Appl Genet 102: 450-457.

Lu S-Y, Hong K-H, Liu S-L, Cheng Y-P, Wu W-L, Chiang T-Y (2002). Genetic variation and population differentiation of Michelia formosana (Magnoliaceae) based on cpDNA variation and RAPD fingerprints: relevance to post-Pleistocene recolonization. I Plant Res 115: 203-216.

Mogensen HL (1996). The hows and whys of cytoplasmic inheritance in seed plants. Am J Bot 83: 383-404.

Myers N, Mittermeier RA, Mittermeier CG, Fonseca GAB, Kent J (2000). Biodiversity hotspots for conservation priorities. Nature 403: 853-858.

Nei M (1987). Molecular Evolutionary Genetics. Columbia University Press: New York.

Newton AC, Allnutt TR, Gillies ACM, Lowe AJ, Ennos RA (1999). Molecular phylogeography, intraspecific variation and the conservation of tree species. Trends Ecol Evol 14: $140-145$.

Okaura T, Harada K (2002). Phylogeographical structure revealed by chloroplast DNA variation in Japanese beech (Fagus crenata Blume). Heredity 88: 322-329.

Prentice HC, Malm JU, Mateu-Andres I, Segarra-Moragues JG (2003). Allozyme and chloroplast DNA variation in island and mainland populations of the rare Spanish endemic, Silene hifacensis (Caryophyllaceae). Conserv Genet 4: 543-555.

Raspe O, Saumitou-Laprade P, Cuguen J, Jacquemart A-L (2000). Chloroplast DNA haplotype variation and population differentiation in Sorbus aucuparia L. (Rosaceae: Maloideae). Mol Ecol 9: 1113-1122.
Shen L, Chen XY, Li YY (2002). Glacial refugia and postglacial recolonization patterns of organisms. Acta Ecol Sin 22 1983-1990.

Shi YF, Cui ZJ, Li JJ (1989). Quaternay Glacials and Environmental Issues of Eastern China. Science Press: Beijing.

Svendsen JI, Astakhov VI, Bolshiyanov DYU (1999). Maximum extent of the Eurasian ice sheets in the Barents and Kara Sea region during the Weichselian. Boreas 28: 234-242.

Szmidt AE, Wang XR (1993). Molecular systematics and genetic differentiation of Pinus sylvestris (L.) and P. densiflora (Sieb. et Zucc.). Theor Appl Genet 86: 159-165.

Szmidt AE, Wang XR, Changtragoon S (1996). Contrasting patterns of genetic diversity in two tropical pines: Pinus kesiya (Royle ex Gordon) and P. merkusii (Jungh et De Vriese). Theor Appl Genet 92: 436-441.

Taberlet P, Gielly L, Pautou G, Bouvet J (1991). Universal primers for amplification of three non-coding regions of chloroplast DNA. Plant Mol Biol 17: 1105-1109.

Tomaru N, Mitsutsuji T, Takahashi M, Tsumura Y, Uchida K, Ohba K (1997). Genetic diversity in Fagus crenata (Japanese beech): influence of the distributional shift during the lateQuaternary. Heredity 78: 241-251.

Uemura K (1997). Cenozoic history of Ginkgo in East Asia. In: Hori T, Ridge RW, Tulecke W, Tredici PD, TremouillauxGuiller J Tobe H (eds) Ginkgo biloba - A Global Treasure from Biology to Medicine. Springer Verlag: Tokyo, pp 207-221.

Wade MJ, McCauley DE (1988). Extinction and colonization their effects on the genetic differentiation of local population. Evolution 42: 995-1005.

Walter R, Epperson BK (2001). Geographic pattern of genetic variation in Pinus resinosa: area of greatest diversity is not the origin of postglacial populations. Mol Ecol 10: 103-111.

Wang XP, Liu YK (1994). Theory and Practice of Biodiversity. China Environmental Science Press: Beijing.

Wang XR, Szmidt AE (1994). Hybridisation and chloroplast DNA variation in a Pinus species complex from Asia. Evolution 48: 1020-1031.

Widmer A, Lexer C (2001). Glacial refugia: sanctuaries for allelic richness, but not for gene diversity. Trends Ecol Evol 16: 267-268.

Willis KJ, McElwain JC (2002). The Evolution of Plants. Oxford University Press: New York.

Xiang H, Tu CL, Xiang YH (2003). A report on Ginkgo resources in Panxian County, Guizhou Province: Guizhou ancient Ginkgo resources investigation 5. Guizhou Sci 21: 159-174.

Xiang YH, Lu XC, Xiang BX (1998). Ancient Ginkgo biloba report II: data of ancient Ginkgo biloba deleted communties in Luping Village and Fengle Town of Wuchuan County Guizhou Province. Guizhou Sci 16: 241-252.

Xiang YH, Xiang BX (1997). Primary report on an ancient Ginkgo biloba deleted community in Wuchuan County, Guizhou Province. Guizhou Sci 15: 239-244.

Xiang YH, Xiang Z (1999). Ancient Ginkgo biloba report III. investigation on ancient Ginkgo biloba remanant population in Guiyang. Guizhou Sci 17: 221-230.

Zhou YL, Bao J, Huang HQ (1982). Research of the gingko's primitive organisms' community in Suizhou Forestry Bureau. Hubei For SciTech 104: 35-38.

Zhou Z, Zheng S (2003). Missing link in Ginkgo evolution. Nature 423: 821-822.

Zhou ZY (2003). Mesozoic Ginkgoaleans: phyogeny, classification and evolutionary trends. Acta Bot Yunnanica 25: 377-396. 